ISSN: 1412-8837

\title{
RESPONS KOMUNITAS NELAYAN TERHADAP MODERNISASI PERIKANAN: STUDI KASUS NELAYAN SUKU BAJO DI DESA LAGASA KABUPATEN MUNA PROVINSI SULAWESI TENGGARA
}

\author{
(Fishery Communities Response To Fishery Modernization: \\ Case Study Bajau Ethnic' Fishermen In Lagasa Village, \\ District Of Muna Southeast Sulawesi)
}

\author{
Awaluddin Hamzah \\ Jurusan Sosial Ekonomi Pertanian \\ Fakultas Pertanian Universitas Haluoleo Kendari
}

\begin{abstract}
Fishery modernization by the Government of Indonesian is intended to alleviate fishery community poverty including for Bajau Ethnic fishermen. This research is aimed at studying the relationship between the meaning of sea and work by fishermen and their acceptance to fishery modernization, impact analyzing of fishery modernization to work pattern, social structure, and the propesperity level. This research is conducted in Lagasa Village, District Of Muna Southeast Sulawesi where Bajau ethnic stay. Respondents consist of 45 ponggawas, 30 local sawies, and 25 sawies from outside village, 5 others as informants. Impacts of modernization to the fisherman community were shown by changes of job pattern that consisted of increasingly the capacity to explore and number of workers (sawi), the character of job tent semi-free labor system, the recruitment of workers became more selective, and the division of labor became more clear and hierarchism. After that, the impacts on the social structure occurred especially on the organizing of sharing holder system that was increasingly more formal, social stratification became more complex, economic activity more differentiated, and the pattern of work relation became semi-exploitative.

Key words: impact of modernization, fisherman community, Bajau ethnic
\end{abstract}

\section{PENDAHULUAN}

Indonesia merupakan sebuah negara yang memiliki beragam suku bangsa yang menyebar dan menetap pada berbagai pulau besar maupun pulau-pulau kecil yang membentang dari Sabang sampai Merauke. Mereka mendiami wilayahwilayah tersebut secara turun temurun dengan kebudayaan, kelembagaan, serta sistem sosial dan ekonomi lainnya masing-masing.

Aktivitas ekonomi tersebut tidak lepas dari interaksi antar individu serta kelompok intern etnis tersebut. Dalam interaksi intern masyarakat dalam satu etnis telah menimbulkan proses sosial dalam masyarakat itu sendiri. Geertz seperti 
dikutip Mubyarto et al (1993) mencatat bahwa di Indonesia terdiri dari kurang lebih 300 etnik (suku bangsa) dengan kebudayaannya sendiri-sendiri, dengan 250 bahasa daerah yang berbeda.

Sebagian suku mendiami kawasan sekitar hutan, yang mengandalkan hidup sebagai petani ladang berpindah atau menggantungkan diri dengan memungut hasil hutan yang menyebabkan mereka hidup terisolasi. Sebagian pula bahkan dalam kuantitas besar masyarakat tinggal dan hidup di daerah pantai dan pesisir, dengan kegiatan ekonomi, sosial dan budaya yang tidak lepas dari laut (nelayan). Kondisi ekologis desa pesisir mempengaruhi aktivitas ekonomi di dalamnya.

Secara geografis, letak kepulauan Nusantara sangat strategis dalam konteks perdagangan laut internasional antara dunia Barat dan Timur. Pada berbagai wilayah tersebut laut merupakan penghubung antara pulau-pulau tersebut disamping sebagai tempat utama kegiatan penangkapan ikan serta hasil laut lainnya oleh nelayan. Kusumastanto (2002) mencatat di Indonesia terdapat 42 kota dan 181 kabupaten terletak di kawasan pesisir. Sumberdaya ikan sebagai bahan konsumsi $90 \%$ berasal dari wilayah pesisir. Sementara Syam sebagaimana dikutip Suhartini, et.al (2005) memperkirakan luas wilayah maritim Indonesia mencapai 5,8 juta $\mathrm{Km}^{2}$ dan dapat menjadi potensi sumberdaya kelautan sebagai salah satu tumpuan harapan masa depan.

Winahyu dan Santiasi dalam Mubyarto et.al (1993) menambahkan dengan membandingkan masyarakat desa pesisir dengan masyarakat lain, nelayan merupakan lapisan yang paling miskin, dibanding dengan komunitas di luar pesisir. Pendapatan yang diperoleh nelayan sifatnya harian dan jumlahnya tidak bisa ditentukan. Selain itu pendapatannya berfluktuasi ditentukan oleh musim serta status nelayan itu sendiri (pemilik kapal atau anak buah).

Berdasarkan ukuran yang dapat dilihat dari rumah tempat tinggal, pakaian, pemenuhan gizi, gaya hidup (life style), status sosial, secara umum nelayan tergolong tidak sejahtera. Pada komunitas nelayan terdapat lingkungan hidup yang kumuh serta rumah-rumah yang sangat sederhana. Hanya sebagian kecil nelayan yang memiliki rumah yang relatif bagus, dan rumah-rumah tersebut umumnya dipunyai oleh pemilik kapal, pemodal, atau rentenir.

Pemerintah memandang perlu untuk memperbaiki taraf hidup nelayan. Usaha tersebut didukung pula oleh pihak pengusaha dalam melihat potensi bisnis perikanan. Realisasinya dilakukan antara lain dalam bentuk modernisasi perikanan 2 Awaludin Hamzah. Respons Komunitas Nelayan Terhadap Modernisasi Perikanan 
(Revolusi Biru) oleh pemerintah dan swasta. Modernisasi yang dilakukan oleh pemerintah dan pihak lain dimaksudkan sebagai bentuk perhatian serta peningkatan kesejahteraan nelayan disamping untuk peningkatan produksi sebagai pemenuhan kebutuhan ikan dalam konteks nasional maupun regional dan lokal. Program tersebut antara lain, bantuan modifikasi sarana penangkapan, pemberian kredit bergulir masyarakat pesisir, penyuluhan lingkungan pesisir dan lautan.

Pada dasarnya setiap program yang bersentuhan langsung dengan masyarakat akan berdampak pada nilai dan norma serta budaya lokal. Demikian pula dengan kelestarian lingkungan laut dan pantai sebagai sumber utama kegiatan nelayan. Hampir seluruh pelaku program berasal dari luar komunitas yang terkadang tidak memikirkan nilai dan norma dalam suatu komunitas, kecuali hanya menjalankan dan mencapai tujuan program. Gejala tersebut ditambah dengan kemudahan akses komunikasi dan informasi yang sangat mudah dapat menggeser nilai ideal menjadi nilai aktual/kenyataan (actual values).

Kehidupan nelayan utamanya lapisan buruh dalam kegiatan produksinya (penangkapan ikan) sebagian besar tergantung dari hubungan baik dengan pihak juragan (pemilik kapal). Hal tersebut dikarenakan kekurangan ataupun ketiadaan modal finansial yang memadai. Kekurangan modal tersebut semakin menambah beban dan tantangan serta persaingan yang besar dalam hal pemanfaatan sumberdaya laut. Di satu sisi nelayan buruh dengan kemampuan serta keterampilan menangkap ikan adalah potensi, di sisi lain tidak adanya modal adalah kendala, mengingat wilayah laut adalah wilayah terbuka yang dapat dimanfaatkan oleh siapa saja yang memiliki kemampuan untuk mengelola sumberdaya.

Intervensi pembangunan ditanggapi beragam oleh berbagai kelompok masyarakat maupun tingkatan stratifikasi nelayan. Dalam komunitas nelayan perubahan yang nampak adalah berubahnya pola kerja, sistem stratifikasi baik karena dasar penguasaan alat produksi maupun mencakup pula kekuasaan. Perubahan strtatifikasi juga terjadi pada organisasi penangkapan sebagai implikasi dari alih teknologi tersebut, sehingga kelembagaan nelayan yang telah terbangun sebelumnya biasanya akan terjadi perubahan pula. Terjadi pula diversifikasi usaha sebagai dampak dari alih teknologi (Satria, 2001) dimana dalam penelitian ini dimasukkan sebagai item modernisasi sektor perikanan. 
ISSN: $1412-8837$

Modernisasi melalui peningkatan dan penggunaan teknologi alat tangkap serta bantuan permodalan berimplikasi pada kegiatan serta organisasi penangkapan ikan dan pada akhirnya terjadi perubahan dalam suatu komunitas. Program motorisasi perahu dan modernisasi perikanan tangkap pada 1980-an yang dikenal dengan istilah Revolusi Biru, menurut Solihin (2005) bukannya menciptakan perikanan tambah maju dan pelakunya (nelayan) menjadi sejahtera.

Hal tersebut menjadi perhatian karena tidak semua lapisan nelayan dapat memanfaatkan peluang modernisasi. Sebelum program modernisasi perikanan oleh pemerintah, nelayan Suku Bajo masih didominasi oleh sistem perikanan tradisional, dimana salah satu cirinya adalah struktur komunitas homogen dan tingkat diferensiasi sosial yang masih rendah. Kehidupan sosial nelayan Suku Bajo setelah berlangsungnya modernisasi menjadi fokus kajian dalam penelitian ini.

Disamping itu nelayan sebagai pihak yang menggunakan teknologi sebagai bagian dari modernisasi tersebut diperhadapkan pada suatu pilihan untuk mengadopsi atau tidak mengadopsi teknologi tersebut. Berbagai faktor yang mempengaruhi adopsi tersebut antara lain adalah bagaimana nelayan tersebut memaknai laut serta pekerjaan nelayan yang digeluti selama ini. Pemaknaan tersebut sangat penting oleh karena mencakup cara pandang mereka terhadap sesuatu/objek yang berkaitan langsung dengan mata pencaharian mereka pada berbagai aspek yakni aspek ekonomi, sosial (sosiologis), religius (teologis), psikologis serta budaya.

Suku Bajo sejak dulu telah menempati laut, pesisir dan kepulauan, bahkan terkesan mereka tidak bisa melangsungkan aktivitasnya di daratan dibanding dengan suku lain seperti Bugis-Makassar yang mampu menyelenggarakan kehidupannya di semua tempat. Hampir setiap program modernisasi berdampak pada kehidupan serta sistem sosial dalam suatu komunitas tertentu. Suku Bajo mayoritas bekerja sebagai nelayan secara turun temurun. Oleh karena kehidupan Suku Bajo sangat dekat dengan laut, maka suatu hal yang perlu dikaji bahwa bagi mereka nelayan dan laut dapat dipandang sebagai budaya, sumber mencari nafkah ataupun sarana pelestarian lingkungan laut dan pesisir. Dinamika kehidupan yang sangat sulit dipisahkan dengan laut, membuat kajian tentang suku Bajo termasuk dari sisi kehidupan sosial menjadi menarik.

Kajian Peribadi (2000) antara lain menyimpulkan bahwa dalam hal usaha mata pencaharian telah terjadi pergeseran dari orientasi sosial kepada orientasi ekonomi. 4 Awaludin Hamzah. Respons Komunitas Nelayan Terhadap Modernisasi Perikanan 
Penelitian lainnya juga dilakukan oleh Wunawarsih (2005) dan mendukung hal tersebut dan menghasilkan kesimpulan relokasi penduduk menyebabkan terjadinya mobilitas vertikal contohnya peralihan posisi sawi menjadi ponggawa. Berbagai program pembangunan perikanan dan kelautan telah menyentuh dan berdampak langsung maupun tidak langsung terhadap kehidupan komunitas Suku Bajo.

Berdasarkan uraian tersebut tujuan penelitian ini adalah untuk mengetahui dampak modernisasi perikanan terhadap struktur sosial nelayan Suku Bajo.

\section{METODE PENELITIAN}

Penelitian dilaksanakan pada bulan Juli sampai dengan September 2007, di Desa Lagasa Kecamatan Duruka Kabupaten Muna Provinsi Sulawesi Tenggara. Jumlah sampel yang dijadikan responden sebanyak 100 orang, yang terdiri darri nelayan pemilik kapal (ponggawa) sebanyak 45 orang, nelayan pekerja (sawi) lokal sebanyak 30 orang, nelayan pekerja (sawi) luar desa sebanyak 25 orang. Informan dalam penelitian ini diperoleh: (a) Kepala Desa, (b) seorang mantan Kepala Desa, (c) Pensiunan Dinas Perikanan Muna berdomisili di desa Lagasa (d) Pegawai TPI, (e) Seorang mantan ponggawa. Metode yang digunakan untuk mengumpulkan data primer adalah dengan menggunakan isian kuesioner, wawancara informan dan responden, serta pengamatan langsung (observasi partisipasi).

Analisa data dilakukan secara deskriptif yakni pengembangan konsep dan menghimpun fakta. Hasil analisa disimpulkan dengan diperkaya hasil wawancara mendalam serta observasi untuk lebih memahami dan mendalami data yang diperoleh melalui quesioner. Analisis data kualitatif dilakukan dengan tahapan reduksi dan penyajian data.

\section{Dampak Modernisasi Perikanan}

\section{HASIL DAN PEMBAHASAN}

Nelayan di Desa Lagasa menggunakan berbagai jenis sarana tangkap berupa perahu dan alat tangkap. Penggunaan berbagai sarana tangkap tersebut terdiri dari perahu tradisional dengan penggerak dayung (boseh) dalam istilah lokal koli-koli, dengan alat tangkap pancing atau jaring tassi. Selanjutnya nelayan menggunakan perahu layar motor (ngkuru-ngkuru), dengan alat tangkap pancing dan jaring tassi (pukak tassi) serta sarana modernisasi berupa penerapan teknologi kapal mini pursein kapasitas 5 - 10 GT dengan alat tangkap pukat cincin (gae). 
ISSN: $1412-8837$

Penggunaan setiap jenis sarana tersebut menimbulkan konsekuensi atau dampak yakni pola kerja, struktur sosial serta tingkat kesejahteraan nelayan. Oleh karena itu setiap peralihan penggunaan sarana tersebut menimbulkan perubahan pula pada pola kerja, struktur sosial serta tingkat kesejahteraan nelayan itu sendiri. Hasil tangkapan yang diperoleh juga berbeda-beda. Pada penggunaan koli-koli hasil yang diperoleh tidak terlalu banyak oleh karena jangkauan melaut hanya pada pinggiran pantai. Pada periode selanjutnya hasil yang diperoleh lebih banyak karena ketergantungan terhadap tenaga fisik nelayan dapat dibantu oleh mesin.

Tabel 1. Perubahan Pola Kerja Penggunaan Jenis Sarana Tangkap

\begin{tabular}{|c|c|c|c|}
\hline \multirow[t]{2}{*}{ Dimensi } & \multicolumn{3}{|c|}{ Jenis Sarana Tangkap } \\
\hline & Koli-Koli & Ngkuru-ngkuru & Gae \\
\hline $\begin{array}{l}\text { Daya Jelajah } \\
\text { Jumlah Pekerja }\end{array}$ & Inshore & inshore & offshore \\
\hline (Sawi) & $2-3$ orang & 3 - 4 orang & 12 - 15 orang \\
\hline a. Sifat & $\begin{array}{c}\text { Bebas } \\
\text { Spontan, }\end{array}$ & Bebas & Semi bebas \\
\hline $\begin{array}{l}\text { b. Pola rekrutmen } \\
\text { Waktu Melaut } \\
\text { Pembagian Kerja }\end{array}$ & $\begin{array}{c}\text { Komunal } \\
\leq 7 \text { jam per hari } \\
\text { Tidak ada }\end{array}$ & $\begin{array}{l}\text { Spontan, Komunal } \\
\leq 7 \text { jam per hari } \\
\text { Ada, kurang jelas }\end{array}$ & $\begin{array}{c}\text { Selektif } \\
>12 \text { jam per hari } \\
\text { Jelas }\end{array}$ \\
\hline
\end{tabular}

Dari segi efisiensi, pekerjaan sawi menjadi lebih ringan dibandingkan ketika menggunakan teknologi lama. Pada masa sebelumnya nelayan memperhitungkan resiko tenaga serta jarak yang sukar dijangkau. Pekerjaan lebih santai, tidak memerlukan tenaga untuk mendayung, serta tidak memerlukan perawatan pukat yang sering seperti jaring kecil sebelumnya.

Implikasi peralihan setiap jenis sarana tangkap adalah berubahnya struktur sosial nelayan. Perubahan ditandai oleh munculnya diferensiasi pekerjaan sebagai konsekuensi penggunaan mesin/motor. Berbagai posisi kerja menyebabkan nelayan terstratifikasi dalam berbagai jenis lapisan. Selain itu terjadinya perubahan pola hubungan menjadi hierarkis tetapi tidak mengarah pada eksploitatif.

Perbedaan posisi (diferensiasi pekerjaan) dalam pola kerja tersebut berimplikasi pada diferensiasi sosial karena posisi tersebut bersifat vertikal dan berjenjang serta hierarkis. Posisi sawi dengan keahlian khusus akan memperoleh bagian lebih banyak dari sawi lainnya. Hal tersebut menjadikan kecenderungan sawi untuk "belajar" sehingga dapat mencapai posisi-posisi yang membutuhkan keahlian khusus. Kecenderungan tersebut terjadi karena dalam aturan bagi hasil 6 Awaludin Hamzah. Respons Komunitas Nelayan Terhadap Modernisasi Perikanan 
posisi-posisi tersebut memperoleh jumlah lebih banyak dari pada posisi yang hanya mengandalkan kekuatan fisik seperti sawi pada umumnya. Walaupun jumlahnya tidak ditetapkan dalam suatu pranata khusus. Bagi gae yang memiliki mesin penarik pukat, posisi tukang tare tidak diperlukan lagi karena digantikan oleh mesin yang digerakan oleh masinis (bas). Sehingga bas biasanya memperoleh hasil pembagian yang cukup banyak. Sistem stratifikasi tersebut memperlihatkan nelayan di Desa Lagasa memiliki sistem stratifikasi terbuka dengan berlakunya sistem achieved status.

Tabel 2. Perubahan Struktur Sosial pada Penggunaan Jenis Sarana Tangkap

\begin{tabular}{|c|c|c|c|}
\hline Dimensi & \multicolumn{3}{|c|}{ Sarana Tangkap } \\
\hline & Koli-Koli & Ngkuru-ngkuru & Gae \\
\hline Diferensiasi & $\begin{array}{l}\text { 1.ponggawa, } \\
\text { 2.sawi }\end{array}$ & $\begin{array}{l}\text { 1. ponggawa, } \\
\text { 2. sawi } \\
\text { 3. tukang lume }\end{array}$ & $\begin{array}{l}\text { 1.nakhoda/ponggawa, 2.bas, } \\
\text { 3.pakacca, } \\
\text { 4tukang listrik,5.tukang } \\
\text { lingkar, 6.tukangtare, } \\
\text { 7.tukang bage, 8.tukang lume }\end{array}$ \\
\hline \multicolumn{4}{|c|}{ Stratifikasi Nelayan } \\
\hline a. Jenis Lapisan & $\begin{array}{l}\text { Atas (Ponggawa), } \\
\text { Bawah (Sawi) }\end{array}$ & $\begin{array}{l}\text { Atas (ponggawa) } \\
\text { Bawah (sawi, } \\
\text { tukang lume) }\end{array}$ & $\begin{array}{l}\text { Atas (Ponggawa) } \\
\text { Menengah (Bas, tukang lingkar, } \\
\text { tukang listrik, pakacca) } \\
\text { Bawah (tukang tare, } \\
\text { tukang bage, tukang lume) }\end{array}$ \\
\hline b.Dasar/ukuran & $\begin{array}{l}\text { kepemilikan, } \\
\text { posisi kerja, } \\
\text { pendapatan }\end{array}$ & $\begin{array}{l}\text { kepemilikan, posisi } \\
\text { kerja, pendapatan }\end{array}$ & $\begin{array}{l}\text { kepemilikan, posisi kerja, } \\
\text { pendapatan }\end{array}$ \\
\hline \multicolumn{4}{|c|}{ Stratifikasi Komunitas } \\
\hline a. Jenis Lapisan & $\begin{array}{l}\text { Atas }(\text { lolo, } \\
\text { kades,imam, } \\
\text { ponggawa) } \\
\text { Bawah }(\text { atta, sawi) }\end{array}$ & $\begin{array}{l}\text { Atas } \\
\text { (lolo,kades,imam, } \\
\text { ponggawa), } \\
\text { Bawah (atta, sawi, } \\
\text { tukang lume) }\end{array}$ & $\begin{array}{l}\text { Atas (kades,imam ponggawa), } \\
\text { Menengah (bas, tukang lingkar, } \\
\text { tukang listrik, pakacca) } \\
\text { Bawah (tukang tare, } \\
\text { tukang bage, tukang lume) }\end{array}$ \\
\hline b. Dasar/ukuran & $\begin{array}{l}\text { kepemilikan dan } \\
\text { kehormatan } \\
\text { (ascribed and } \\
\text { achieved status) }\end{array}$ & $\begin{array}{l}\text { kepemilikan dan } \\
\text { kehormatan } \\
\text { (ascribed and achieved } \\
\text { status) }\end{array}$ & $\begin{array}{l}\text { kepemilikan, posisi kerja, } \\
\text { pendapatan (achieved status) }\end{array}$ \\
\hline Pola hubungan & $\begin{array}{l}\text { non eksploitatif, } \\
\text { egaliter }\end{array}$ & $\begin{array}{l}\text { non eksploitatif, } \\
\text { egaliter }\end{array}$ & non eksploitatif, heirarkis \\
\hline Sistem bagi hasil & $\begin{array}{l}50 \% \text { hasil sawi } \\
\text { diserahkan pada } \\
\text { ponggawa }\end{array}$ & $\begin{array}{l}\text { potong tengah (biaya } \\
\text { perasional) } \\
50 \% \text { (ponggawa) } \\
50 \% \text { (sawi) }\end{array}$ & $\begin{array}{l}\text { potong tengah (biaya } \\
\text { operasional) } \\
50 \% \text { (ponggawa): } \\
50 \% \text { (sawi) }\end{array}$ \\
\hline
\end{tabular}


ISSN: $1412-8837$

Pada armada yang menggunakan mesin gardang, perekrutan sawi menjadi lebih selektif lagi. Dua buah armada dengan ponggawa HA memiliki sebuah mesin gardang. Sawi yang hanya mengandalkan kekuatan fisik tidak terlalu menjadi prioritas untu bekerja pada gae gardang.

Tabel 3. Posisi Baru dalam Pola Kerja Armada Gae

\begin{tabular}{|c|c|c|}
\hline No & Posisi & Tugas \\
\hline 1. & Nakhoda/ponggawa & $\begin{array}{l}\text { - Mengemudikan kapal } \\
\text { - Menentukan arah kapal } \\
\text { - Menentukan lokasi penangkapan }\end{array}$ \\
\hline 2. & Masinis/Bas & $\begin{array}{l}\text { - Mengoperasikan mesin } \\
\text { - Merawat dan memperbaiki mesin }\end{array}$ \\
\hline 3. & Pakacca & $\begin{array}{l}\text { - Mengamati kelayakan jumlah ikan sebelum } \\
\text { ditarik }\end{array}$ \\
\hline 4. & Tukang Listrik & $\begin{array}{l}\text { - Menjalankan dan mengoperasikan mesin } \\
\text { generator }\end{array}$ \\
\hline 5. & Tukang Lingkar & - Melingkarkan pukat di sekeliling lampu \\
\hline 6. & Tukang Tare & - Menarik pukat ke atas kapal \\
\hline 7. & Tukang Bage & $\begin{array}{l}\text { - Memilah ikan sesuai jenis dan ukurannya } \\
\text { - membagi bonus (jame-jame) bagi sawi }\end{array}$ \\
\hline 8. & Tukang Lume & $\begin{array}{l}\text { - Membersihkan air laut dan kotoran lain yang } \\
\text { masuk ke dalam kapal }\end{array}$ \\
\hline
\end{tabular}

Sementara itu, terjadi pula perubahan kesejahteraan nelayan setiap penggunaan sarana tersebut. Kesejahteraan tersebut berdasarkan indikator pendapatan, pola makan, kondisi rumah, pendidikan serta cara berpakaian anggota keluarga nelayan. Peningkatan pendapatan tersebut adalah sebagai implikasi dari alih teknologi sarana penangkapan. Penggunaan mesin pada perahu akan memudahkan kelompok nelayan untuk menentukan wilayah tangkapan tanpa mempertimbangkan tenaga untuk mendayung. Ukuran perahu yang lebih besar juga memungkinkan kapasitas muatan hasil tangkapan lebih besar. Disamping itu alat tangkap yang lebih modern juga menghasilkan tangkapan yang lebih banyak dibanding sarana sebelumnya. Perubahan pendapatan nelayan dapat dilihat pada Tabel (4).

8 Awaludin Hamzah. Respons Komunitas Nelayan Terhadap Modernisasi Perikanan 
Tabel 4. Peningkatan Pendapatan Nelayan pada Sarana Tangkap

\begin{tabular}{lccc}
\hline \multirow{2}{*}{ Status Nelayan } & \multicolumn{3}{c}{$\begin{array}{c}\text { Pendapatan pada } \\
\text { Sarana Tangkap (liter beras) }\end{array}$} \\
\cline { 2 - 4 } & Koli-Koli & Ngkuru-ngkuru & Gae \\
\hline Ponggawa $(\mathrm{n}=45)$ & 111 & 247.7 & 1040 \\
Sawi Lokal $(\mathrm{n}=30)$ & 47 & 80.6 & 234.1 \\
Sawi Luar $(\mathrm{n}=23)$ & 46.5 & 84.4 & 232.3 \\
\hline
\end{tabular}

Walaupun terjadi peningkatan pendapatan, berdasarkan metode identifikasi Bangdes, periode penggunaan gae tersebut secara rata-rata nelayan digolongkan pada kelompok masyarakat miskin bagi sawi yakni berpendapatan kurang dari 360 $\mathrm{kg}$ beras. Secara visual dalam hal gaya hidup serta bentuk rumah dan perabot di dalamnya terdapat 25 responden (55.5\%) ponggawa memiliki rumah permanen (dinding tembok) pada rumah di daratan serta 20 (44.4\%) rumah di atas air dengan kontruksi kayu kelas I dan kelas II yang memiliki perabot rumah tangga serta mebeler lainnya. Sedangkan bagi sawi lokal dan luar desa menggunakan rumah kontruksi semi permanen. Semua anggota keluarga nelayan pernah mengenyam pendidikan minimal tingkat SD dan tidak terdapat (0\%) buta huruf.

\section{SIMPULAN DAN SARAN}

\section{Simpulan}

Modernisasi perikanan pada komunitas nelayan membawa dampak pada berbagai segi kehidupan nelayan. Penggunaan setiap jenis sarana tersebut menimbulkan konsekuensi atau dampak yang terjadi yakni pola kerja, struktur sosial serta tingkat kesejahteraan nelayan. Pola kerja pada setiap tahap peralihan teknologi dari yang paling sederhana yakni koli-koli, ngkuru-ngkuru sampai pada kapal motor gae menunjukan peningkatan efektifitas dan efisiensi pekerjaan.

Dampak selanjutnya adalah berubahnya struktur sosial nelayan. Perubahan ditandai oleh timbulnya diferensiasi pekerjaan sebagai konsekuensi penggunaan mesin/motor maupun alat tangkap yang lebih modern. Berbagai posisi kerja menyebabkan nelayan terstratifikasi dalam berbagai jenis lapisan. Oleh karena pada beberapa aktivitas penangkapan membutuhkan tenaga kerja yang terampil, maka pembagian kerja (diferensiasi) mulai berlaku. Diferensiasi pekerjaan tersebut menyebabkan pula terjadinya diferensiasi sosial. Diferensiasi sosial nelayan tersebut menyebabkan perubahan struktur sosial dalam kehidupan nelayan. Perubahan 
ISSN: $1412-8837$

tersebut berupa perubahan pola hubungan egaliter menjadi hierarkis tetapi tidak bersifat eksplotatif. Pada sistem stratifikasi, pada konteks komunitas, dasar pelapisan berubah dari ascribed dan achieved status menjadi hanya berdasar achieved status.

Hubungan antara ponggawa sebagai pemilik sarana produksi serta sawi sebagai pekerja bukanlah bersifat eksploitatif, karena diantara mereka masih berlaku nilainilai budaya saling membantu baik dalam kelompok kerja maupun kehidupan sehari-hari. Sehingga pola hubungan tidak bersifat eksploitatif serta saling membutuhkan dengan kata lain perbedaan tersebut tidak menunjukan gejala polarisasi oleh karena masih berlakunya tradisi Bajo untuk saling membantu.

\section{Saran}

Laut sebagai wilayah open acces serta sumberdaya common property menyebabkan munculnya persaingan antar nelayan, sehingga nelayan kecil menjadi tersingkirkan. Oleh karena itu, dalam hal pemberian bantuan serta program pengembangan masyarakat pantai, pemerintah hendaknya memperhatikan aspek sosial, budaya serta tingkat kebutuhan nelayan itu sendiri. Pelaksanaan program yang tidak memperhatikan aspek tersebut dapat menyebabkan tujuan program yang tidak tercapai misalnya penolakan untuk mengadopsi, ataupun berdampak pada rusaknya kehidupan sosial nelayan.

Salah satu aspek yang perlu menjadi bahan pertimbangan pemerintah adalah bagaimana pemerintah mengetahui sejauhmana pemaknaan nelayan tersebut terhadap laut maupun pekerjaannya sebagai nelayan. Program yang berkaitan dengan nelayan adalah sinergi antara aspek ekonomi dan aspek budaya. Hal tersebut disebabkan bahwa pada kelompok nelayan terjadi kecenderungan pergeseran makna ke arah komersil (ekonomis) namun tidak meninggalkan makna budaya. Untuk itu diperlukan interaksi intensif dengan mengikuti tradisi-tradisi komunitas setempat bagi pemerintah secara informal serta meminimalisir "jarak" antara pemerintah dan nelayan.

Selanjutnya oleh karena ketimpangan pendapatan antara nelayan lapisan atas dan lapisan bawah cukup besar, maka perlu adanya kelembagaan sosial (pranata) komunitas dalam hal sistem imbalan antara lapisan atas (ponggawa) dengan lapisan bawah (sawi) sehingga ketimpangan pendapatan pada masing-masing lapisan lebih kecil, serta dapat meredam terjadinya konflik sosial nelayan. Hal tersebut dapat 
dilakukan dengan membuat aturan bagi hasil maupun sistem imbalan lainnya yang mendapat legalitas dari pemerintah.

Penelitian ini dilakukan pada salah satu komunitas Suku Bajo dengan interaksi sosial dengan suku lainnya cukup sering, disamping mudahnya akses komunikasi dan informasi. Oleh karena itu penelitian selanjutnya sebaiknya pada Suku Bajo, yang masih relatif jauh dengan komunitas suku lain serta terbatasnya akses informasi dan komunikasi. Hal tersebut sangat penting, untuk mengetahui gambaran Suku Bajo yang lebih lengkap.

Dalam hal dampak modernisasi pada kesejahteraan, sebaiknya analisa lebih tajam dilakukan pada pengeluaran rumah tangga nelayan. Hal tersebut dikaitkan dengan apakah sikap dan perilaku boros yang selama ini menjadi stereotype nelayan terdapat pula pada nelayan Suku Bajo. Analisa pengeluaran tersebut menjadikan katagori kelayakan hidup nelayan lebih terukur.

\section{DAFTAR PUSTAKA}

Kusumastanto, T 2002. Reposisi Ocean Policy dalam Pembangunan Ekonomi Indonesia di Era Otonomi Daerah. Orasi Ilmiah Guru Besar Tetap Ilmu Kebijakan Ekonomi Perikanan dan Kelautan. Bogor: FPIK- IPB.

Satria A. 2002. Pengantar Sosiologi Masyarakat Pesisir. Jakarta: Cidesindo.

Solihin, A. 2005 Merancang Revitalisasi Perikanan. www.penulislepas.com (18 September 2005)

Suhartini, A Halim, I Hambali dan A Basyid (Eds). 2005. Model-Model Pemberdayaan Masyarakat. Yogyakarta: LKiS

Wariyanto, A. 2004. Perlu Pemberdayaan Nelayan. http://www.kalyanamitra.or.id (10 April 2004)

Winahyu dan Santiasi. 1993. Pengembangan Desa Pantai, dalam Mubyarto dkk, Dua Puluh Tahun Penelitian Pedesaan. Yogyakarta: Aditya Media. 